SANTOS FGB; NEGREIROS MZ; MEDEIROS JF; LOPES WAR; SOARES AM; NUNES GHS; FREITAS FCL. 2014. Growth and yield of Cantaloupe melon 'Acclaim' in protected cultivation using agrotextile. Horticultura Brasileira 32: 55-62.

\title{
Growth and yield of Cantaloupe melon 'Acclaim' in protected cultivation using agrotextile
}

\author{
Francisco GB Santos ${ }^{1}$; Maria Z Negreiros ${ }^{2}$; José F Medeiros ${ }^{2}$; Welder AR Lopes ${ }^{2}$; Alinne M Soares ${ }^{2}$; \\ Glauber HS Nunes'; Francisco CL Freitas ${ }^{2}$ \\ ${ }^{1}$ IFCE, Campus Crato, Rod CE 292 km 06, Bairro Gisélia Pinheiro, 63115-500 Crato-CE; gaubertob@gmail.com; ${ }^{2}$ UFERSA, Depto. \\ Ciências Vegetais, BR 110 km 47, Presidente Costa e Silva, 59625-900 Mossoró-RN; zuleide@ufersa.edu.br; jfmedeir@ufersa.edu.br; \\ welder.lopes@hotmail.com; alinne_menezes@hotmail.com; glauber@ufersa.edu.br; fclaudiof@yahoo.com.br
}

\begin{abstract}
In Rio Grande do Norte, the melon growers have been using the row cover on the roof of the plants to start flowering in order to reduce the population of insect pests that cause severe losses, rising production costs, especially with the application of defensive. Thus, it is important to know the best time to remove the row cover because, due to its use, it is assumed that there are changes in the physiological response of plants. In order to evaluate the growth and yield of the melon plants 'Acclaim' cultivated under protection agrotextile (TNT) for different periods, a trial was conducted at the Universidade Federal Rural do Semi-árido, Mossoró, Rio Grande do Norte state. The experimental design was a randomized complete block, with four replications, in a splitplot, the plots were the plant protection periods $(0,18,21,24,27$ and 30 days after transplanting, DAT), and splitplots, times of sampling the plants $(13,20,27,34$, 41, 48 and 55 DAT). We evaluated the dry matter accumulation in leaves (LDMA), branches (BDMA), flowers (FDMA), fruits (FrdMA) and total (TDMA), assimilate partitioning, leaf area index (LAI), leaf weight ratio (LWR), absolute growth rate (AGR) and relative (RGR), net assimilation rate (NAR), total (PTOT) and marketable productivity (PCOM). The treatments with plant protection did not affect the TDMA which peaked at 295.12 g plant $^{-1}$ at 53 DAT, with the fruits behaving like sink preferred plant, accounting for $72.25 \%$ of the dry mass accumulated. The LAI and the AGR grew by 55 and 42 DAT (1.95 and $18.518 \mathrm{~g} /$ plant/day), respectively, while the LWR and RGR decreased over the cycle, with peaks of 0.911 and 0.242 $\mathrm{g} / \mathrm{g} / \mathrm{day}$, at 13 and 20 DAT, respectively. The PTOT and PCOM were not affected by periods of plant protection, with averages of 29.30 and $22.25 \mathrm{tha}^{-1}$, respectively, indicating that it is possible to manage the row cover in order to remove it later, that reduces costs and crop protection without significant loss in productivity.
\end{abstract}

Keywords: Cucumis melo, TNT, growth rate, marketable production.

\section{RESUMO}

Crescimento e produtividade de melão Cantaloupe 'Acclaim' em cultivo protegido utilizando agrotêxtil

No Rio Grande do Norte, os produtores de melão utilizam agrotêxtil na cobertura das plantas até o início da floração, para reduzir a população de pragas que causam sérios prejuízos à cultura. Desta forma, é importante saber o momento da retirada do agrotêxtil porque, decorrente de seu uso, presume-se que ocorram alterações fisiológicas nas plantas. Com o objetivo de avaliar o crescimento e produtividade de plantas de melão Cantaloupe 'Acclaim' cultivadas sob proteção com agrotêxtil (TNT), realizou-se um experimento na Universidade Federal Rural do Semi-árido em Mossoró-RN. O delineamento foi de blocos casualizados completos, com quatro repetições, dispostos em parcelas subdivididas, tendo nas parcelas os períodos de proteção de plantas [0, 18, 21, 24, 27 e 30 dias após o transplantio (DAT)], e nas subparcelas, as épocas de amostragens das plantas (13, 20, 27, 34, 41, 48 e 55 DAT). Foram avaliados o acúmulo de massa seca nas folhas (AMSFO), ramos (AMSR), flores (AMSF), frutos (AMSFR) e total (AMST), partição de assimilados, índice de área foliar (IAF), razão de peso foliar (RPF), taxa de crescimento absoluto (TCA) e relativo (TCR), taxa assimilatória líquida (TAL), produtividade total (PTOT) e comercial (PCOM). Os tratamentos com agrotêxtil não afetaram o AMST que atingiu o máximo de 295,12 g planta-1 $^{-1}$ aos 53 DAT, com os frutos se comportando como dreno preferencial da planta, sendo responsáveis por $72,25 \%$ da massa seca acumulada. O IAF e a TCA apresentaram crescimento até 55 e 42 DAT (1,95 e 18,518 g/ planta/dia) respectivamente, enquanto a RPF e a TCR decresceram ao longo do ciclo, com máximos de 0,911 e 0,242 g/g/dia, aos 13 e 20 DAT, respectivamente. A PTOT e PCOM não foram afetadas pelos períodos de proteção das plantas, com médias de 29,30 e 22,25 tha ${ }^{-1}$, respectivamente, indicando que é possível, manejar o agrotêxtil de modo a retirá-lo tardiamente, o que reduz custos com defensivos e sem prejuízos significativos na produtividade.

Palavras-chave: Cucumis melo, TNT, taxa de crescimento, produção comercial.

(Recebido para publicação em 2 de setembro de 2012; aceito em 14 de outubro de 2013) (Received on September 2, 2012; accepted on October 14, 2013)

$\mathrm{M}$ elon is the vegetable that contributes the most to the Brazilian trade balance. In 2011, 101 thousand tons of melon was exported to the European Union, which generated revenue of US\$ 78 million. Of the 13,400 ha of melon grown in Brazil, in 2011, the States of Ceará and Rio Grande do Norte contributed with 11,490 ha, that means, $85.75 \%$. Approximately $80 \%$ of the production in these states is for the external market, whereas $20 \%$ are sold domestically (Melão, 2011).

In the latest years, noble melon cultivars, as of the group Cantaloupe, presenting more attractive organoleptic features and higher commercial value, increased its market share $15-20 \%$, 
although more sensitive, requiring more advanced cultivation techniques (Damasceno et al., 2012).

The growth analysis has been largely used to investigate the influence of agronomic practices which modify the environment of the crops, in an attempt to explain differences in growth, because of genetics or resulting from environmental changes (Lopes et al., 2011). This method evaluates the net production of plants derived from the photosynthetic process, and it is the result of the performance of assimilatory system during a certain period of time, describing the plant morphology in different time intervals between successive samples (Benincasa, 2003).

The dry matter accumulation and increase of leaf area, quantified as a function of time, are used in the estimation of several physiological indices related to performance differences between cultivars and plant communities in many ecophysiological studies (Lima et al., 2007). The distribution of the dry mass is the final result of the flow of the assimilates of the source organs for the sink organs, considering that this distribution between the sinks of a plant is primarily regulated by themselves (Marcelis, 1996).

Several agronomic practices are used to manipulate the partitioning between the assimilates in many crops, as fruit thinning, growth inhibitors and control of pollination in order to improve the development of the fruit. However, the literature on manipulating the source-drain for melon still focuses as regards the biomass of fruits (Long et al., 2004).

In the agricultural center, also called "Agropolo", of Mossoró-Assu in Rio Grande do Norte, since 2001, the melon growers have been using the white nonwoven fabric as a row cover on the roof of the plants until the beginning of flowering, with the goal of reducing the population of insect pests (whitefly and minadora) which have been causing severe losses in the yield and quality of fruits, raising production costs with the use of both manpower and with the application of pesticides (Medeiros et al., 2008).
The nonwoven fabric (TNT) is made from long strands of polypropylene which are placed in layers and welded together at appropriate temperatures and, TNT is a very light material (16-25 $\mathrm{g} \mathrm{m}^{-2}$ ) of adequate strength to be used in agriculture (Dantas, 2010). It has the advantage of easy handling; it can be placed and removed at any stage of development of the crop, using structure as a support or placed as floating row cover directly over the plants (Barros Júnior et al., 2004).

The use of the row cover conditions changes in the physiological response of plants by modifying the source: drain ratios. Thus, it is important to know the best time to remove the row cover. One of the changes is the delay of the fruiting by the use of the row cover, because while the plants are protected under the cover, the flowers are unavailable for pollination performed by the bees. Long et al. (2004), working on delay of pollination with the use of the row cover, found that this delay allows the plant to invest the available photoassimilates in vegetative growth, increase in the number of female flowers available for pollination and later, in subsequent fixation of a higher number of fruits per plant, altering the source-sink ratios, production and fruit quality. Thus, it is necessary to evaluate the effects on growth, so as to contribute to the planning of cultivation method which expresses the maximum yield potential of the plants.

In Brazil, some studies have shown the importance of knowledge about the growth and physiological indices as well as the influence of agronomic practices and external factors on the final production of the plant (Medeiros et al., 2006, 2007; Morais et al., 2008), however studies related to this subject about the delay of removing the row cover, as a resource to change the source-drain ratios in melon production, are not common.

The aim of this work was to evaluate the growth and yield of Cantaloupe melon 'Acclaim' cultivated under protection using TNT for different periods in Mossoró, Rio Grande do Norte state.

\section{MATERIAL AND METHODS}

The experiment was carried out in the Vegetable Garden of the Plant Sciences Department of the Universidade Federal Rural do Semi-árido in Mossoró, Rio Grande do Norte state, Brazil ( $5^{\circ} 11^{\prime} \mathrm{S}$, $37^{\circ} 20^{\prime} \mathrm{W}$, altitude of $18 \mathrm{~m}$ ), from July 22 to October 5, 2010. The climate of the region, according to Köppen is BSwh', that means, dry and very hot, with two climate seasons: a dry season, which is usually from June to January and another rainy season from February to May (Carmo Filho et al., 1991) and soil classified as Eutrophic yellow red Argisols, sandy loam texture.

The experimental design used was randomized complete blocks, with four replications. The treatments were arranged in split plots, the plots being periods of plant protection with the white agricultural textile $(0,18,21,24$, 27 and 30 DAT), and the split plots, sampling dates of plants $(13,20,27,34$, 41, 48 and 55 DAT).

Each experimental unit occupied an area of $60 \mathrm{~m}^{2}$ with $8 \mathrm{~m}$ wide and 7.5 $\mathrm{m}$ long, spaced $2.0 \mathrm{x} 0.3 \mathrm{~m}$, comprising four rows of plants. The useful portion area of the plot was $27.6 \mathrm{~m}^{2}(6.9 \times 4$ $\mathrm{m})$, consisting of two central rows, to evaluate the yield and the two lateral rows for growth analysis. The two plants of extremities were considered as borders, totaling 23 plants per row and 46 per plot.

The soil preparation consisted of harrowing followed by furrows in rows, spaced $2 \mathrm{~m}$ and depth of $0.2 \mathrm{~m}$, which was held the fertilization with compost Pole fértil ${ }^{\circledR}$, corresponding to $7.5 \mathrm{tha}^{-1}$ with subsequent closing of the furrows using animal traction and build up the ridges.

After the installation of drip irrigation system, the soil cover application was done. The application was with double-sided polyethylene film (black and silver), silver face upwards, over the ridges and, then arches of rigid polyethylene were placed in order to support the TNT cover. The opening of the planting holes, with a punch of $6 \mathrm{~cm}$ in diameter and spaced 0.3 
$\mathrm{m}$ to facilitate the transplantation of seedlings, was performed. Cantaloupe melon 'Acclaim' was transplanted on 08/02/2010, 12 days after sowing, and the number of plants in a row was corrected by replanting seedlings up to five days after transplantation. After transplantation of the seedlings, the TNT of white polypropylene or agrotextile row cover was placed, covering the plants, weight $15 \mathrm{~g} \mathrm{~m}^{-2}$ and $1.4 \mathrm{~m}$ width, except for control plots which remained uncovered.

The topdressing was carried out by fertirrigation during the crop cycle, $90 \mathrm{~kg} \mathrm{ha}^{-1}$ of $\mathrm{N}, 70 \mathrm{~kg} \mathrm{ha}^{-1}$ of $\mathrm{P}_{2} \mathrm{O}_{5}$ and $120 \mathrm{~kg} \mathrm{ha}^{-1}$ of $\mathrm{K}_{2} \mathrm{O}$ in the urea form, purified MAP, potassium chloride, calcium nitrate, magnesium sulphate and nitric acid were used. As a source of micronutrients, at 27 days after transplanting (DAT), $0.6 \mathrm{~kg} \mathrm{ha}^{-1}$ of the commercial formulation containing: 5.0\% B, 1.5\% Cu, 4\% Fe, 5.4\% Mg, 4, $0 \% \mathrm{Mn}, 0.1 \% \mathrm{Mo}, 3.0 \% \mathrm{~S}$ and $1.5 \% \mathrm{Zn}$ was applied.

The control of pests and diseases was performed according to the conventional recommendations; however monitoring was carried out, with periodicity of three days, observing the level of economic damage to whitefly (Bemisia tabaci) and Lyriomyza huidobrensis. The control of weeds was performed manually using hoes between the beds of plots and manually between plants.

During the crop cycle, seven plant extractions were performed and the growth analysis was carried out. After each extraction, the plants were partitioned into branches, leaves, flowers and fruits, packed in identified paper bags and placed in a forced circulation of air chamber at temperature of $65^{\circ} \mathrm{C}$ until constant mass.

The characteristics evaluated were: dry mass accumulation in the leaves (LDMA), the branches (BDMA), the flowers (FDMA) and fruits (FrDMA) and total dry mass of aboveground part (TDMA), obtained by weighing the dry matter of each organ. The leaf area was obtained by the disk method (TavaresJunior et al., 2002), which consisted of removing disks of a known area, fresh leaves, using a cork punch. With the dry mass of the leaves (LDM) and dry mass of the disks (DMDi) and from the knowledge of the area of the disk (ADi), the leaf area was calculated: leaf area $(\mathrm{LA})=(\mathrm{LDM} A D i) / \mathrm{DMDi}$, in that, LDM, leaf dry mass, ADi, the area of the disks, and DMDi, dry mass of the disks.

To ensure the effectiveness of this method, a validation procedure was performed. Prior to removal of leaf discs sampled, they were scanned along with a metric scale and using the image software SigmaScan Pro 5.0 ${ }^{\circ}$, the leaf area was calculated. After obtaining the leaf areas using the two methods, a relation between them was established and a correlation coefficient for the disk method was calculated, so that the leaf area was given by the equation $\mathrm{F}$ $=[(\mathrm{LDM} \mathrm{ADi}) / \mathrm{MSDi}] \mathrm{x}$ correlation coefficient.

From the available data of the dry masses and the leaf area, the following characteristics, according to the methodology of Benincasa (2003), were determined: Leaf area index (LAI): $\mathrm{LAI}=\mathrm{LA} / \mathrm{S}$, LA was the leaf area and S was the available space for the plant, in this case it was considered as available 200x30 cm. Leaf weight ratio: LWR = LDM/TDM, ratio between the dry mass in the leaves (LDM) and the total dry mass in the plant (TDM). The absolute growth rate $\mathrm{AGR}=(\mathrm{W} 2-\mathrm{W} 1) /(\mathrm{T} 2-\mathrm{T} 1)$ (g/plant/day); the relative growth rate $\mathrm{RGR}=(\ln (\mathrm{W} 2)-\ln (\mathrm{W} 1)) /(\mathrm{T} 2-\mathrm{T} 1)$ (g/g/day), where $\ln (\mathrm{W} 2)$ and $\ln (\mathrm{W} 1)$ were the natural logarithms of the dry matter in two successive samplings; net assimilation rate of the shoot NAR $=[(\mathrm{W} 2-\mathrm{W} 1) /(\mathrm{T} 2-\mathrm{T} 1)] \times[(\ln (\mathrm{LA} 2)-$ $\ln (\mathrm{LA} 1)) /(\mathrm{LA} 2-\mathrm{LA} 1)]\left(\mathrm{g} / \mathrm{cm}^{2} / \mathrm{day}\right)$. For all the equations, W2 and W1 were the dry matter of two successive samplings, $\mathrm{T} 2$ and $\mathrm{T} 1$ represented the sampling time. The time difference was set at seven days and LA2 and LA1 represented the leaf area in two successive samplings.

The total productivity was obtained through individual weighing of all the fruits of the useful area of each treatment. The weighing and estimation in relation to one hectare provided the total productivity in $\mathrm{t} \mathrm{ha}^{-1}$. For marketable productivity: the firm fruits were considered marketable fruits, homogeneous with respect to color, good roughness of the rind, without deformation, wilting, cracks and signs of rot, insect pest attacks and mechanical damage.

Data were subjected to analysis of variance using the software SISVAR and regressions using the software Table Curve 2D v5.01 (Jandel Scientific, 1991) and means were compared by Tukey test at 5\% probability.

\section{RESULTS AND DISCUSSION}

A significant interaction between sampling times (DAT) and the periods when the plants were temporarily under TNT protection for dry mass accumulation in leaves (LDMA) was verified. The treatments remained under protective TNT up to 24 and 30 DAT, an increase in biomass up to 50 DAT (62.13 g plant $\left.^{-1}\right)$ and 45 DAT (55.95 g plant $\left.^{-1}\right)$, respectively, was observed. After these days, the biomass decrease (Figure 1A); probably, the predominance of senescence on the issuance of new leaves was the cause of this decline. In other treatments in which plants remained under the protection of TNT (0, 18, 21 and 27 DAT), similar results were observed, with dry mass accumulation increased up to the date of the last sampling at 55 DAT, when they reached maximum LDMA (Figure 1A). Small increases from the beginning of the reproductive stage (27 DAT) are due to diversion of drains in the plant, especially for fruit.

Analyzing the periods in which the plants remained protected, within each period of the collection of the plants, significant differences, only at 55 DAT, were noticed, when the treatment without the protection of the plants was the treatment which provided higher dry mass accumulation $(85.39 \mathrm{~g}$ plant $^{-1}$ ), not differing from the treatment with protection up to 18 DAT (70.22 g plant $\left.{ }^{-1}\right)$. LDMA lower average was obtained when the plants were under protection during 30 DAT $(41.81 \mathrm{~g}$ plant $^{-1}$ ), not differing from 21,24 and 27 days of protection, with averages of 55.32, 59.00 and $62.55 \mathrm{~g} \mathrm{plant}^{-1}$, respectively (Table 1 ). The results of LDMA of this experiment were higher than the results observed by Pereira et al. 
(2011) with Charentais melon 'Fleuron' cultivated under different shading nets, in Viçosa, Minas Gerais state, which can be explained due to being two different types of melons, Cantaloupe and Charentais, and different environmental cultivation conditions. The Charentais melon was grown in full sun and under shade conditions throughout the cycle, whereas the Cantaloupe under the TNT protection up to certain periods of the crop cycle.
The accumulation of the dry mass of branches (BDMA) was only affected by sampling time. BDMA reached the maximum estimated of $19.84 \mathrm{~g} \mathrm{plant}^{-1}$ at 49 DAT, presenting, from this value, a trend toward the decline up to 55 DAT (Figure 1B), due to a greater allocation of photoassimilates for the reproductive structures, in detriment of vegetative parts.

The dry mass accumulation in the flowers (FDMA) was influenced only by the sampling time, presenting an increasing behavior started at 13 DAT and reaching maximum value of 1.80 $\mathrm{g} \mathrm{plant}^{-1}$ at 35 DAT, when this value decreased up to the end the evaluation period (Figure 1C).

The dry mass accumulation in the fruits (FrDMA) was affected only by the sampling time. The fruiting started around 27 DAT, causing more intense allocation of photoassimilates for

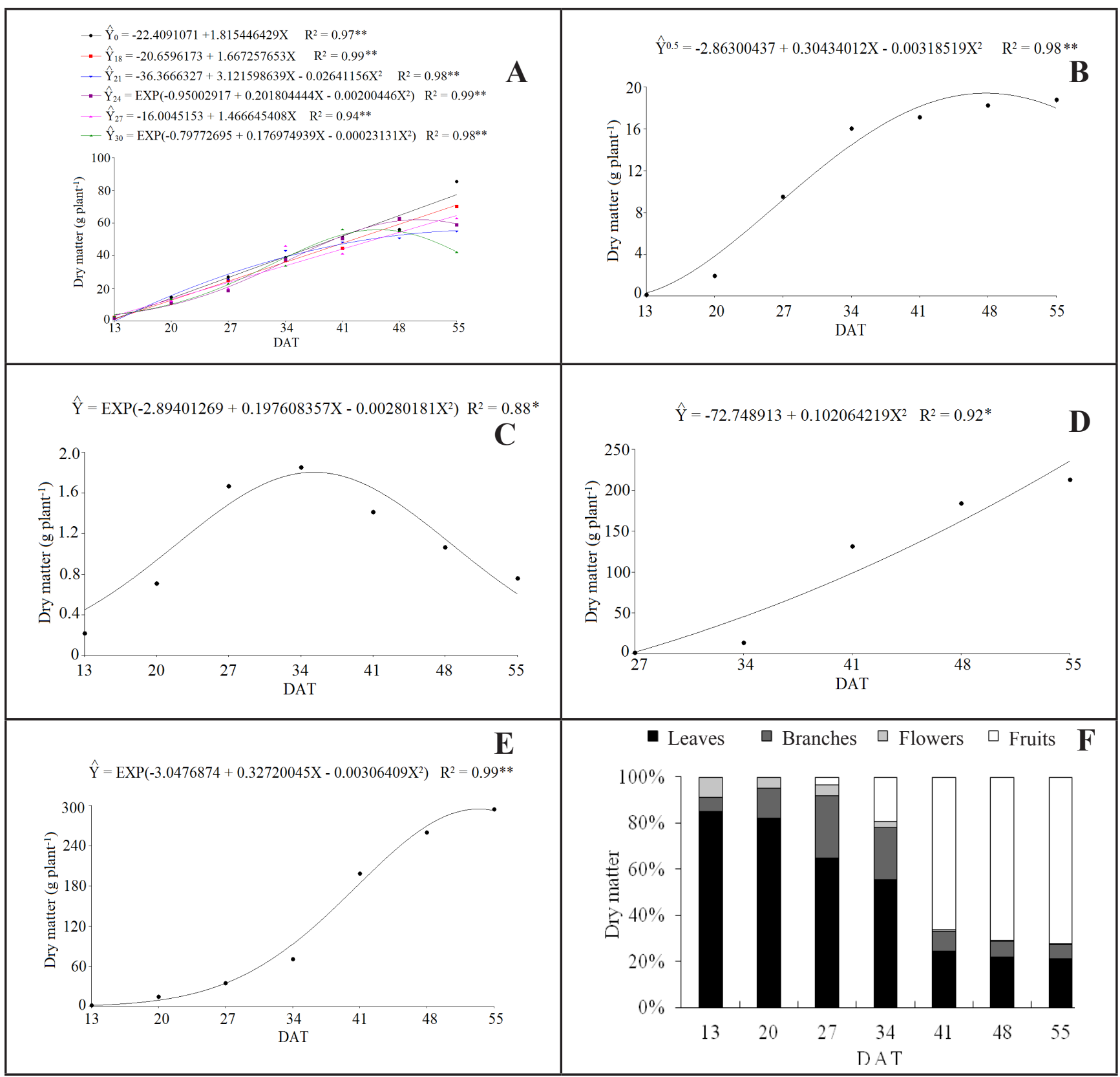

Figure 1. Dry matter accumulation in leaves (A), branches (B), flowers (C), fruits (D), and total (E) and assimilate partition (F) of melon plants grown under row cover on different times after transplantation (DAT) [acúmulo de massa seca de folhas (A), ramos (B), flores (C), frutos (D), total (E) e partição de assimilados (F) de plantas de melão 'Acclaim' cultivado sob proteção com agrotêxtil branco em diferentes épocas após o transplantio]. Mossoró, UFERSA, 2010. 


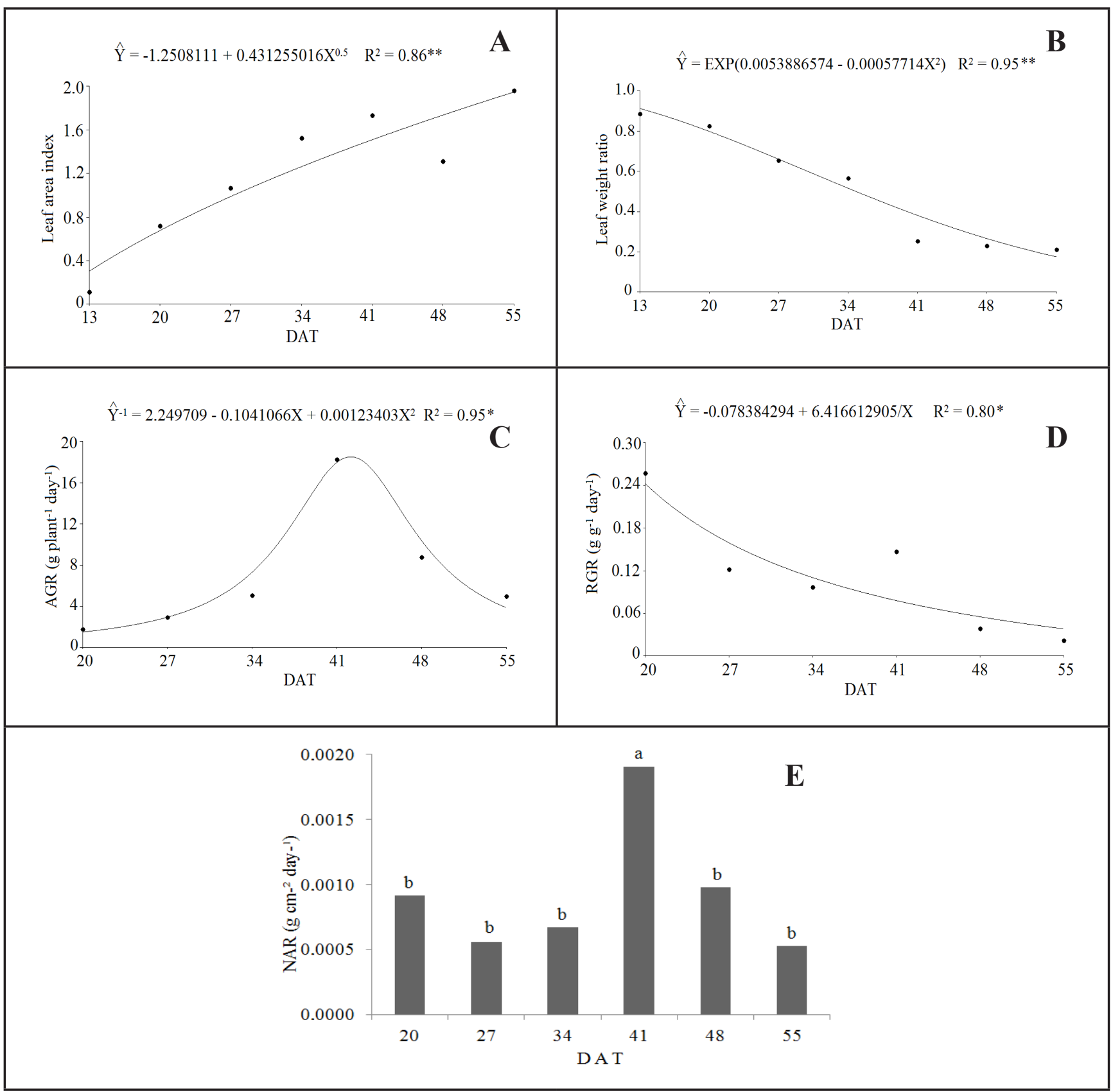

Figure 2. Leaf area index (A), leaf weight ratio (B), absolute growth rate (D), relative growth rate (E) and net assimilation rate (F) of melon plants grown under row cover on different times after transplantation [índice de área foliar (A), razão de peso foliar (B), taxa de crescimento absoluto (C), taxa de crescimento relativo (D) e taxa assimilatória líquida (E) de plantas de melão ‘Acclaim' cultivado sob proteção com agrotêxtil branco em diferentes épocas após o transplantio]. Mossoró, UFERSA, 2010.

these organs drains, and an increasing accumulation of dry mass was observed. Between 27 and 55 DAT, when the dry mass accumulation in the fruits reached the maximum value, the values changed from 1.656 to $235.995 \mathrm{~g} \mathrm{plant}^{-1}$, which corresponded to an estimated increase of dry mass of $234.339 \mathrm{~g} \mathrm{plant}^{-1}$, or $14,250.9 \%$ (Figure 1D).

When the offer of assimilates is insufficient to meet the potential growth of all organs, a competition is established and the distribution of assimilates depends on the strength of the drain of each organ (Duarte et al., 2008). The strength of the drain of an organ refers to its size. In the case of the melon plant, the strength of an individual fruit is far superior to most vegetable fruits, because whereas a fruit of melon can accumulate an average of $2.4 \mathrm{~g} \mathrm{day}^{-1}$ of dry mass, the tomato fruit accumulates an average of $0.129 \mathrm{~g}$ day $^{-1}$ (Heuvelink, 1997).

The accumulation of the total dry mass of the aboveground part (TDMA) was influenced only by the sampling time, with slow response up to about 27 DAT, increasing from this time, with the entrance of the plant in the reproductive phase, and intensifying during 34-48 DAT. The maximum TDMA value was observed at 53 DAT, 
Table 1. Mean values of dry mass of leaves (LDM) of melon plants 'Acclaim' cultivated under protection cover of white agrotextile (TNT) on different times after transplanting (PDAT) [valores médios de massa seca de folhas (MSFO) de plantas de melão 'Acclaim' cultivado sob proteção com agrotêxtil branco (TNT) por diferentes períodos após o transplantio (PDAT)]. Mossoró, UFERSA, 2010.

\begin{tabular}{|c|c|c|c|c|c|c|c|}
\hline \multirow{2}{*}{ PDAT } & \multicolumn{7}{|c|}{ LDM (g plant $\left.{ }^{-1}\right)$} \\
\hline & 13 DAT & 20 DAT & 27 DAT & 34 DAT & 41 DAT & 48 DAT & 55 DAT \\
\hline 0 & $2.40 \mathrm{a}$ & $14.63 \mathrm{a}$ & $26.85 \mathrm{a}$ & $38.86 \mathrm{a}$ & $51.18 \mathrm{a}$ & $55.90 \mathrm{a}$ & $85.39 \mathrm{a}$ \\
\hline 18 & $2.03 \mathrm{a}$ & $10.96 \mathrm{a}$ & $24.98 \mathrm{a}$ & $37.24 \mathrm{a}$ & $44.41 \mathrm{a}$ & $62.34 \mathrm{a}$ & $70.22 \mathrm{ab}$ \\
\hline 21 & $2.24 \mathrm{a}$ & $12.16 \mathrm{a}$ & $25.70 \mathrm{a}$ & $43.44 \mathrm{a}$ & $48.52 \mathrm{a}$ & $51.04 \mathrm{a}$ & $55.32 \mathrm{bc}$ \\
\hline 24 & $1.71 \mathrm{a}$ & $11.38 \mathrm{a}$ & $18.67 \mathrm{a}$ & $37.74 \mathrm{a}$ & $50.51 \mathrm{a}$ & $62.72 \mathrm{a}$ & $59.00 \mathrm{bc}$ \\
\hline 27 & $2.26 \mathrm{a}$ & $11.82 \mathrm{a}$ & $19.55 \mathrm{a}$ & $45.54 \mathrm{a}$ & $40.84 \mathrm{a}$ & $54.47 \mathrm{a}$ & $62.55 \mathrm{bc}$ \\
\hline 30 & $2.34 \mathrm{a}$ & $12.85 \mathrm{a}$ & $22.42 \mathrm{a}$ & $33.51 \mathrm{a}$ & $55.80 \mathrm{a}$ & $54.62 \mathrm{a}$ & $41.81 \mathrm{c}$ \\
\hline $\mathrm{CV}(\%)$ & \multicolumn{7}{|c|}{28.08} \\
\hline
\end{tabular}

Means followed by the same letter in the column do not differ by Tukey test at $5 \%$ (médias seguidas pela mesma letra, nas colunas, não diferem entre si pelo teste de Tukey a 5\% de probabilidade).

Table 2. Mean values of total and marketable productivity of melon 'Acclaim' cultivated under protection cover of white agrotextile (TNT) on different times after transplanting (PDAT) [valores médios de produtividade total e comercial de melão 'Acclaim' cultivado sob proteção com agrotêxtil (TNT) por diferentes períodos após o transplantio (PDAT)]. Mossoró, UFERSA, 2010.

\begin{tabular}{lcc}
\hline PDAT & Total yield $\left(\mathbf{t} \mathbf{h a}^{-1}\right)$ & Marketable yield $\left(\mathbf{t ~ h a} \mathbf{~}^{-1}\right)$ \\
\hline 0 & $32.64 \mathrm{a}$ & $25.25 \mathrm{a}$ \\
18 & $27.32 \mathrm{a}$ & $19.25 \mathrm{a}$ \\
21 & $32.70 \mathrm{a}$ & $26.25 \mathrm{a}$ \\
24 & $27.85 \mathrm{a}$ & $22.75 \mathrm{a}$ \\
27 & $26.09 \mathrm{a}$ & $20.25 \mathrm{a}$ \\
30 & $29.20 \mathrm{a}$ & $19.75 \mathrm{a}$ \\
\hline Mean & 29.30 & 22.25 \\
CV $(\%)$ & 12.87 & 16.51 \\
\hline
\end{tabular}

Means followed by the same letter in the column do not differ by Tukey test at $5 \%$ (médias seguidas pela mesma letra, nas colunas, não diferem entre si pelo teste de Tukey a $5 \%$ de probabilidade).

with average of $295.12 \mathrm{~g} \mathrm{plant}^{-1}$ (Figure 1E). Similar response was observed in 'Gália' (Oliveira et al., 2008) and 'Mandacaru' melon, in Mossoró (Paes, 2011). While with Charentais melon 'Fleuron' cultivated under different shading nets, an increase of total dry mass up to 54.2 DAT was verified, for the control treatment (full sun) and up to 55 DAT with net aluminet ${ }^{\mathbb{Q}}$, followed by a period of reduction. The maximum values for the accumulation of dry mass were $225.27 \mathrm{~g}$ plant $^{-1}$, full sun, followed by $206.18 \mathrm{~g}$ plant $^{-1}$ with aluminet ${ }^{\circledR}$ (Pereira et al., 2011). The Charentais melon presented a longer production cycle, 105 days after sowing (DAS), whereas the Cantaloupe, shorter, 67 DAS, which can explain the different behavior of the total dry mass accumulation of the melon plant cycle. When compared to other regions, the melon cultivated in the Brazilian Northeast has a fairly short cycle, on average 60 to 65 days.

The distribution of assimilates in different organs of melon plants followed the same pattern for all periods of temporary protection with TNT. With the onset of fruiting, 27 DAT, the allocation of the assimilates from the leaves to the fruit is so intense. Branches up to 27 DAT, flowers and fruits behave as a drain, however the fruits are the preferred drain of the plant and reached the end of the cycle with $72.25 \%$, at 55 DAT, whereas the leaves accounted for only $21.13 \%$, branches $6.36 \%$ and flowers $0.26 \%$ of dry mass accumulation (Figure 1F).

The distribution of dry mass in the plant organs may suffer variations due to inherent characteristics of the cultivar used, the cropping system or region. In Cantaloupe melon, Costa et al. (2006) observed that of the total of dry mass accumulated by the plant, the vegetative part contributed $33 \%$ and the fruits $67 \%$. Porto (2003) observed that by the end of the cycle of melon plant, the contribution of the leaves, branches and fruits was of 28,10 and $65 \%$, respectively. Queiroga et al. (2008) verified that the fruits were responsible for $71.15 \%$ of the total dry mass accumulation for the hybrids of 'Torreon' and 'Coronado' melon.

The LAI was influenced only by the sampling time; the curve for this index displaying a rising tendency, showing that as the leaf area grows, the LAI grows, reaching the maximum value of $1.95 \mathrm{~cm}^{2} / \mathrm{cm}^{2}$ at 55 DAT (Figure 2A). Similar response was observed by Paes (2011) with Inodorus melon 'Mandacaru' under TNT protection and mulching, in Mossoró. In both works, the maximum value for IAF was obtained at 55 days after transplanting.

The leaf weight ratio (LWR) was affected only by the sampling time. The LWR was high in the beginning of the cycle of the plant growth, presenting the maximum value of 0.911 at 13 DAT (Figure 2B), showing greater allocation of assimilates for the leaves. At this time, the leaves behaved as preferential metabolic drain on the partitioning 
of assimilates when they participated with $85.19 \%$ of the total dry mass of the plant (Figure 1F). The response curve for LWR was downward (Figure 2B), showing that other plant organs have been given dominion over the distribution of assimilates along the crop cycle (Figure 1F).

The absolute growth rate (AGR) was affected only by the sampling time. The AGR which represents daily gain of dry matter of a plant without considering the starting material existing increased until the estimated value of $18.518 \mathrm{~g} / \mathrm{plant} /$ day, at 42 DAT, then it decreased until the end of the cycle when the daily dry matter accumulation reached $1.512 \mathrm{~g} /$ plant/day (Figure 2C).

The values of AGR in this experiment were higher than the results found by Costa et al. (2006) for Cantaloupe melon in the conditions of Jaboticabal, São Paulo state, conducted vertically in greenhouse with average AGR of $2.88 \mathrm{~g} / \mathrm{plant} /$ day and maximum value, approximately, of $4.5 \mathrm{~g} / \mathrm{plant} /$ day. According to Brandão Filho \& Vasconcelos (1998), melon is a plant of fast growth and, in ideal conditions, it is able to grow about $4 \mathrm{~cm}$ during the day and $3 \mathrm{~cm}$ overnight. The weather conditions in the Agricultural Center of Mossoró is excellent for melon, mainly in the second semester of the year, and as no adverse weather conditions were observed during the experiment, probably these were the conditions which allowed a higher daily gain of biomass.

The intense allocation of the photoassimilates for the fruits and the maintenance of the existing organs probably contributed to reduce, throughout the cycle, the plant efficiency in daily dry matter production. This decrease was also observed by Paes (2011) in 'Mandacaru' melon cultivated with row cover and mulching and by Morais et al. (2008) in 'Goldex' melon in Mossoró.

The relative growth rate (RGR), which expresses the increase in dry mass in relation to the pre-existing biomass, was influenced only by the sampling time, showing always decreasing responses (Figure 2D). The maximum value of RGR was $0.242 \mathrm{~g} / \mathrm{g} / \mathrm{day}$ reached at 20 DAT, declining thereafter until the end of the evaluation period. This behavior of the melon plant was also observed by other authors (Farias et al., 2003; Costa et al., 2006; Morais et al., 2008; Paes, 2011).

Decreases in the values of RGR throughout the cycle are common for most species, including melon. With the increase of accumulated dry matter by the plant, it increases the need for photoassimilates for maintenance of already formed organs (leaves, branches, flowers and fruits). According to Benincasa (2003), all growth will result in the production of sufficient material to meet the metabolic needs of existing material and also to store or build new structural material. Thus, the amount of photoassimilates available for growth (RGR) tends to be lower as the plant grows, and the quantity of material produced is used, largely, to meet the metabolic needs, for example, cellular respiration (Braga et al., 2011). Decreases in RGR values are related to declines in net assimilation rate (NAR) and leaf area ratio (Fontes et al., 2005; Lopes et al., 2011).

The net assimilation rate (NAR), like AGR and RGR, was affected only by the sampling time (DAT). No mathematical model was designed to explain the response to this characteristic in relation to DAT, however a significant difference was observed, using the Tukey test at $5 \%$ probability. The NAR that reflects the size of the assimilating system involved in the production of the dry matter (estimated net photosynthesis), reached the maximum value of $0.0019 \mathrm{~g} /$ $\mathrm{cm}^{2} /$ day at 41 DAT, not differing among other evaluation periods. Decreases in the values of NAR, with the age of the plant, were verified in melon by Paes (2011) and also in other vegetable crops such as tomatoes (Lopes et al., 2011).

In 'Mickylee' watermelon, Braga et al. (2011) verified that NAR was growing up to $35 \mathrm{DAT}$, showing a decrease from this date. Farias et al. (2003) and Morais et al. (2008) found higher values for NAR in melon cultivation early in the crop cycle. Different responses in NAR can be observed in cucurbits, varying according to the material studied, conduction system, cultural practices employed among others.

Protection of plants with TNT for different periods after transplanting of seedlings (DAT) did not significantly affect total and marketable yield of Cantaloupe melon 'Acclaim' which ranged respectively from 26.09 to $32.70 \mathrm{t} \mathrm{ha}^{-1}$ and 19.25 to $26.25 \mathrm{t} \mathrm{ha}^{-1}$ (Table 2). It is noteworthy that despite the costs to purchase the TNT and recycled hose arches used in treatments, these materials can be reused, besides the maintenance of the plants under TNT protection for 30 DAT provided cost savings in the acquisition and application of pesticides.

However, the temporary protection of the aboveground part of the melon plant with TNT in studies carried out in Mexico and Brazil, including the Northeast Region, resulted in higher marketable yield of this vegetable. Ibarra et al. (2001) found that black polyethylene mulching alone and/or in combination with the temporary protection of the aboveground part of melon cv. Crusier with TNT protection up to 10, 20 and 32 days after planting (DAP) resulted in earlier plants with higher marketable and total yields compared to the control, without the protection. In Baraúna, Rio Grande do Norte state, Medeiros et al. (2007), keeping the Cantaloupe melon 'Torreon' protected with TNT up to 28 DAT verified a significant increase of $16.43 \%$ and $12.96 \%$, respectively, in the number of total and marketable fruits. The different productive performance of the Cantaloupe melon protected temporarily with TNT in different regions, including this study, can be explained by the genotype $\mathrm{x}$ environment interaction. The environment involves a number of conditions under which plants are grown. In this sense, the environment can be a location, year, cultural practice, planting season or even a combination of all these factors (Romagosa \& Fox, 1993).

According to the results obtained, this study found that the treatments with TNT protection affected only the LDMA at 55 DAT. BDMA, FDMA and FrDMA showed growth up to 48, 35 and 53 DAT, respectively, decreasing subsequently. 
The fruits behaved as a preferred drain of the plant, responsible for $72.25 \%$ of the accumulated dry mass at the end of the cycle. The LAI and AGR showed growth up to 55 and 42 DAT, while the LWR and RGR decreased throughout the cycle. The total and marketable yields were not affected by the periods of plant protection, with averages of 29.30 and $22.25 \mathrm{t} \mathrm{ha}^{-1}$, respectively, pointing out that it is possible to manage the TNT in the melon plant, in order to remove it later, which reduces the costs of phytosanitary treatments of insect pests and without significant losses in the marketable yield of fruits.

\section{REFERENCES}

BARROS JUNIOR AP; GRANGEIRO LC; BEZERRA NETO F; NEGREIROS M Z; SOUZA JO; AZEVEDO PE; MEDEIROS DC. 2004. Cultivo da alface em túneis baixos de agrotextil. Horticultura Brasileira 22: 801-803.

BENINCASA MMP. 2003. Análise de crescimento de plantas: noções básicas. 2. ed. Jaboticabal: FUNEP, 42p.

BRAGA DF; NEGREIROS MZ; FREITAS FCL; GRANGEIRO LC; LOPES WAR. 2011. Crescimento de melancia "Mickylee" cultivada sob fertirrigação. Revista Caatinga 24: 49-55.

BRANDÃO FILHO JUT; VASCONCELOS MAS. 1998. A cultura do meloeiro. In: GOTO R; TIVELLI SW. Produção de hortaliças em ambiente protegido, condições subtropicais. São Paulo. Fundação Editora da UNESP. p.161-193.

CARMO FILHO F; ESPÍNOLA SOBRINHO J; MAIA NETO JM. 1991. Dados climatológicos de Mossoró: um município semi-árido nordestino. Mossoró: ESAM. 121p.

COSTA CC; CECILIO FILHO AB; REZENDE BLA; BARBOSA JC. 2006. Crescimento e partição de assimilados em melão cantaloupe em função de concentrações de fósforo em solução nutritiva. Científica 34: 126-130.

DAMASCENO APAB; MEDEIROS JF; MEDEIROS DC; MELO IGC; DANTAS DC. 2012. Crescimento e marcha de absorção de nutrientes do melão Cantaloupe tipo "harper" fertirrigado com doses de N e K. Revista Caatinga 25: 137-146.
DANTAS MSM. 2010. Rendimento e qualidade de frutos de melancia cultivada sob proteção agrotêxtil combinado com mulching plástico. Mossoró: UFERSA. 50p (Dissertação mestrado).

DUARTE TS; PEIL RMN; MONTEZANO EM. 2008. Crescimento de frutos de meloeiro sob diferentes relações fonte:dreno. Horticultura Brasileira 26: 342-347.

FARIAS CHA; ESPINOLA SOBRINHO J; MEDEIROS JF; COSTAMC; NASCIMENTO LD; SILVA MCC. 2003. Crescimento e desenvolvimento da cultura do melão sob diferentes lâminas de irrigação e salinidade da água. Revista Brasileira de Engenharia Agrícola e Ambiental 7: 445-450.

FONTES PCR; DIAS EN; SILVA DJH. 2005. Dinâmica do crescimento, distribuição de matéria seca na planta e produção de pimentão em ambiente protegido. Horticultura Brasileira 23: 94-99.

HEUVELINK E. 1997. Effect of fruit load on dry matter partitioning in tomato. Scientia Horticulturae. 69: 51-59.

IBARRA L; FLORES J; DIAZ-PÉREZ JC. 2001. Growth and yield of muskmelon in response to plastic mulch and row covers. Scientia Horticulturae 87: 139-145.

JANDEL SCIENTIFIC. 1991. Table Curve: curve fitting software. Corte Madera: Jandel Scientific. 280p.

LIMA JF; PEIXOTO CP; LEDO CAS. 2007. Índicies fisiológicos e crescimento inicial de mamoeiro (Carica papaya L.) em casa de vegetação. Ciência e Agrotecnologia 31: 1358-1363.

LONG RL; WALSH KB; MIDMORE DM; ROGERS G. 2004. Source-sink manipulation to increase melon (Cucumis melo) fruit biomass and soluble sugar content. Australian Journal of Agricultural Research 55: 12411251.

LOPES WAR; NEGREIROS MZ; DOMBROSKI JLD; RODRIGUES GSO; SOARES AM; ARAÚJO AP. 2011. Análise do crescimento de tomate 'SM-16' cultivado sob diferentes coberturas de solo. Horticultura Brasileira 29: 554-561.

MARCELIS LFM. 1996. Sink strength as a determinant of dry matter partitioning in the whole plant. Journal of Experimental Botany 47: 1281-1291.

MEDEIROS EV; SERAFIM ECS; GRANGEIRO LC, SOBRINHO JE; NEGREIROS MZ; SALES JÚNIOR R. 2008. Influência do agrotextil sobre a densidade populacional de Monosporascus cannonballus em solo cultivado com melancia (Citrullus lanatus).
Ciência e Agrotecnologia 32: 797-803.

MEDEIROS JF; SANTOS SCL; CÂMARA MJT; NEGREIROS MZ. 2007. Produção de melão Cantaloupe influenciado por coberturas do solo, agrotêxtil e lâminas de irrigação. Horticultura Brasileira 25: 538-543.

MEDEIROS JF; SILVA MCC; CÂMARA NETO FG; ALMEIDA AHB; SOUZA JO; NEGREIROS MZ; SOARES SPF. 2006. Crescimento e produção de melão cultivado sob cobertura do solo e diferentes freqüências de irrigação. Revista Brasileira de Engenharia Agrícola e Ambiental 10: 792-797.

MELÃO: Oferta elevada no $2^{\circ}$ semestre reduz preços. 2011. Hortifruti Brasil 108: 37-37.

MORAIS ERC; MAIA CE NEGREIROS MZ; ARAÚJO JUNIOR BB; MEDEIROS JF. 2008. Crescimento e produtividade do meloeiro Goldex influenciado pela cobertura do solo. Scientia Agraria 9: 129-137.

OLIVEIRA FA; MEDEIROS JF; LIMA CJGS; DUTRA I; OLIVEIRA MKT. 2008. Crescimento do meloeiro Gália fertirrigado com diferentes doses de nitrogênio e potássio. Caatinga 21: 168-173.

PAES RA. 2011. Cultivo de melão com agrotêxtil combinado com Mulch plástico. Mossoró: UFERSA. 86p. (Tese doutorado).

PEREIRA FHF; PUIATTI M; FINGER FL; CECON PR. 2011. Growth, assimilate partition and yield of melon charenthais under different shading screens. Horticultura Brasileira 29: 91-97.

PORTO DRQ. 2003. Crescimento e partição de assimilados em melão cantaloupe cultivado sob diferentes coberturas de solo e lâminas de irrigação. Mossoró: UFERSA. 40p (Monografia graduação).

QUEIROGA RCF; PUIATTI M; FONTES PCR; CECON PR. 2008. Partição de assimilados e índices fisiológicos de cultivares de melão do grupo Cantaloupensis influenciado por número e posição de frutos na planta em ambiente protegido. Ceres 55: 596-604.

ROMAGOSA I; FOX PN. 1993. Genotype x environment interactions and adaptation. In: HAYWARD MD; BOSEMARK NO; ROMAGOSA I (eds). Plant breeding: principles and prospect. London: Chapman \& Hall. Chapter 20, p.375-390.

TAVARES-JUNIOR JE; FAVARIN JL; DOURADO-NETO D; MAIA AHN; FAZUOLI LC; BERNARDES MS. 2002. Análise comparativa de métodos de determinação de área foliar em cafeeiro. Bragantia 16: 199-203. 